\title{
Brewer's Spent Grains Protects against Oxidative DNA Damage in Saccharomyces cerevisiae
}

\author{
Manuela M. Moreira ${ }^{1,2}$, Daniel O. Carvalho ${ }^{1}$, Rui Oliveira ${ }^{3}$, Björn Johansson ${ }^{4} \&$ Luís F. Guido $^{1}$ \\ ${ }^{1}$ REQUIMTE/LAQV, Departamento de Química e Bioquímica, Faculdade de Ciências, Universidade do Porto, \\ Porto, Portugal \\ ${ }^{2}$ REQUIMTE/LAQV, Instituto Superior de Engenharia do Porto, Instituto Politécnico do Porto, Porto, \\ Portugal \\ 3 CITAB, Center for the Research and Technology of Agro-Environmental and Biological Sciences, \\ Departamento de Biologia, Universidade do Minho, Campus de Gualtar, Braga, Portugal \\ ${ }^{4}$ CBMA, Centre of Molecular and Environmental Biology, Departamento de Biologia, Universidade do Minho, \\ Campus de Gualtar, Braga, Portugal \\ Correspondence: Luís F. Guido, REQUIMTE/LAQV, Departamento de Química e Bioquímica, Faculdade de \\ Ciências, Universidade do Porto, Rua do Campo Alegre 687, 4169-007 Porto, Portugal. Tel: 351-220-402-644. \\ E-mail:1fguido@fc.up.pt
}

Received: March 12, 2017 Accepted: May 8, $2017 \quad$ Online Published: June 15, 2017

doi:10.5539/jas.v9n7p12 URL: https://doi.org/10.5539/jas.v9n7p12

The research is financed by European Union (FEDER Funds through COMPETE) and National Funds (FCT, Fundação para a Ciência e a Tecnologia).

\begin{abstract}
Brewer's spent grain (BSG), obtained from barley malt during brewing, contains high amounts of phenolic acids, predominantly ferulic and $p$-coumaric acids. The protective effects of BSG extracts against oxidative DNA damage induced by $\mathrm{H}_{2} \mathrm{O}_{2}$ in Saccharomyces cerevisiae cells were investigated using an optimized yeast comet assay and flow cytometry. The results indicated that BSG extracts from black malt exhibited a 5 -fold reduction in the genotoxic effects of $\mathrm{H}_{2} \mathrm{O}_{2}$, compared to the 2-fold decrease by the $\mathrm{BSG}$ extracts from pilsen malts. Flow cytometry analysis with dichlorofluorescein diacetate demonstrated that the intracellular oxidation of $S$. cerevisiae is also reduced to approximately $50 \%$ in the presence of 20 -fold diluted BSG extracts. BSG extracts obtained from pilsen and black malt types exert dose-dependent protective properties against the genotoxic effects induced by ROS and decrease intracellular oxidation of yeast cells.
\end{abstract}

Keywords: barley, brewer's spent grain, phenolic compounds, antigenotoxic activity, yeast comet assay, brewer's yeast

\section{Introduction}

Brewer's spent grain (BSG) is the resultant residual solid fraction of barley malt after wort production for the brewing industry. BSG is a unique source of bioactive ingredients such as hydroxycinnamic acids ferulic and p-coumaric acids (Meneses, Martins, Teixeira, \& Mussatto, 2013; Moreira, Morais, Barros, Delerue-Matos, \& Guido, 2012; Moreira et al., 2013; Mussatto, Dragone, \& Roberto, 2007). Several studies demonstrate that extracts containing hydroxycinnamic acids hold important health benefits, including antioxidant or free radical scavenging (Shahidi \& Chandrasekara, 2010), anti-carcinogenic (Gomes et al., 2003), anti-inflammatory (Kim et al., 2012) and antigenotoxic (McCarthy et al., 2012) properties. Currently, BSG is used in animal feed as a source of protein and fiber, providing all the essential amino acids in combination with other nitrogen sources (Mussatto, Dragone, \& Roberto, 2006). Furthermore, new applications of the by-products from the brewing industry would be an advantage due to the increasing costs for their disposal (Vieira et al., 2014).

Reactive oxygen species (ROS), such as the superoxide radical $\left(\mathrm{O}_{2}{ }^{\circ}\right)$, hydroxyl radical $\left({ }^{\circ} \mathrm{OH}\right)$ and hydrogen peroxide $\left(\mathrm{H}_{2} \mathrm{O}_{2}\right)$, may induce cell oxidative damage. $\mathrm{O}_{2}{ }^{-}$and $\mathrm{H}_{2} \mathrm{O}_{2}$ can undergo the Fenton reaction in the presence of redox-active metal ions, such as iron, generating the extremely reactive ${ }^{\circ} \mathrm{OH}$. Formed radicals may 
lead to the damage of cell components, including DNA (Henle, Luo, Gassmann, \& Linn, 1996). In a situation of DNA oxidative damage, cell cycle is arrested for the activation of repair mechanisms and if damage cannot be repaired, mechanisms of programmed cell death are activated. The principal DNA repair pathways are base excision repair (BER) by removing oxidation damaged single bases and nucleotide excision repair (NER), which is involved in repairing bulky DNA lesions caused by ultraviolet light (Azevedo, Marques, Fokt, Oliveira, \& Johansson, 2011).

The DNA damage can be evaluated using the comet assay, where the chromosomal DNA migration distance by electrophoresis correlates with the extent of DNA damage. The comet assay has been used for a variety of applications with several organisms (Rank, Syberg, \& Jensen, 2009) and was also optimized for application in yeast cells (Saccharomyces cerevisiae) (Azevedo et al., 2011; Marques, Azevedo, Johansson, \& Oliveira, 2011). Azevedo et al. (2011) reported an optimized comet assay protocol for yeast cells to evaluate DNA damage and oxidative damage caused by $\mathrm{H}_{2} \mathrm{O}_{2}$ with high sensitivity and reproducibility.

Several studies have focused on the antioxidant properties of BSG (Bartolomé, Santos, Jiménez, del Nozal, \& Gómez-Cordovés, 2002; Meneses et al., 2013), however, to our knowledge, only one has reported the antigenotoxic activity of BSG extracts. McCarthy et al. (2012) have showed phenolic BSG extracts are able to protect against DNA damage in human lymphocytic U937 cells using the comet assay. The current study aimed at investigating the protective effects of BSG phenolics against DNA oxidative damage in $S$. cerevisiae. Yeast $S$. cerevisiae has been chosen has an eukaryotic model to study the cellular response against stress damages due to biochemical and molecular similarities with human cells (Mager \& Winderickx, 2005). A recent study by our group on the evaluation of antioxidant activity and identification of the major phenolic compounds of BSG from six malt types (pilsen, melano, melano 80, carared, chocolate and black) has revealed that pilsen BSG exhibits higher total phenolic content and antioxidant activity and black BSG, the lower (Moreira et al., 2013). Therefore, BSG samples used in this study were those whose differences were more pronounced, corresponding to BSG obtained from pilsen and black malts. We have examined whether these extracts could inhibit oxidative DNA damage induced by $\mathrm{H}_{2} \mathrm{O}_{2}$ using a recently developed comet assay applied to yeast.

\section{Method}

\subsection{Chemicals and Samples}

All reagents were of analytical grade and were purchased from Sigma-Aldrich, unless otherwise stated. BSG samples used in this work were kindly supplied by Unicer - Bebidas de Portugal, S.A. (S. Mamede de Infesta, Portugal) and obtained from barley malt samples supplied by Os Três Cervejeiros, Lda (Porto, Portugal). BSG samples investigated in this work were chosen according to the more pronounced differences in total phenolic content and antioxidant activity, evaluated in a previous work (Moreira et al., 2013), and correspond to BSG samples obtained from pilsen and black malts. Pilsen malt produces very light colored, clean and crisp worts and is used as base malt for all beer styles. The color ranges from 3.5 to $5.7 \mathrm{EBC}$ units and kilning temperature between 80 to $85{ }^{\circ} \mathrm{C}$. Black malt is roasted for a higher period and the end temperature is very high $\left(230{ }^{\circ} \mathrm{C}\right)$, forming harsher flavors and $\mathrm{EBC}$ color ranges from 1350 to 1500 units. The BSG samples used for phenolics extraction correspond to the remaining solid fraction obtained following the removal of wort during the pilot scale production of beer in the brewing process. For wort production it was followed the procedure previously described (Moreira et al., 2013), and the obtained solid residue was frozen, lyophilized and then finely ground.

\subsection{BSG Phenolic Extracts}

Phenolics were extracted from dried BSG samples according to the microwave-assisted extraction (MAE) procedure previously optimized (Moreira et al., 2012). After MAE, the extracts were centrifuged and the $\mathrm{pH}$ of the supernatant was adjusted to $\mathrm{pH} 6.5$ with $\mathrm{HCl} 6 \mathrm{M}$. After filtration through a cellulose filter $(0.45 \mu \mathrm{m})$, the extracts were stored at $-20^{\circ} \mathrm{C}$ until further analysis.

\subsection{Yeast Strain, Culture Media and Growth Conditions}

The $S$. cerevisiae yeast strain BY4741 (MAT $\alpha$ his $3 \Delta 1$ leu $2 \Delta 0$ met15 $\Delta 0$ ura3 $\Delta 0$ ) was used in this work. Strain were maintained on standard solid yeast extract $(1 \% \mathrm{w} / \mathrm{v})$, peptone $(2 \% \mathrm{w} / \mathrm{v})$, dextrose $(2 \% \mathrm{w} / \mathrm{v})$ and agar $(2 \%$ w/v) medium (YPD). Yeast cells were grown in $50 \mathrm{~mL}$ liquid YPD medium in an Erlenmeyer flask with air-liquid ratio of $5 / 1$, at $30^{\circ} \mathrm{C}$ and orbital agitation at $200 \mathrm{rpm}$. Growth was monitored by measuring the optical density at $600 \mathrm{~nm}\left(\mathrm{OD}_{600}\right)$.

\subsection{Viability Assays}

A pre-culture prepared in YPD medium, with a single yeast colony and grown overnight, was diluted to a density of $1.2 \times 10^{7}$ cells $/ \mathrm{mL}$ in fresh medium and harvested by centrifugation $\left(2 \mathrm{~min}\right.$ at $\left.5000 \mathrm{rpm}, 4{ }^{\circ} \mathrm{C}\right)$ after two 
generations. Cells were subsequently washed twice, each time with the same volume of sterilized deionized water. Pre-treatment with BSG extracts was made by ressuspending the pellet in the same volume of $1 / 2$ diluted BSG extracts (1:1 (v/v) YPD 2-fold concentrated and BSG extract). Cells with BSG extracts were incubated at $30^{\circ} \mathrm{C}, 200 \mathrm{rpm}$ for $90 \mathrm{~min}$. Samples were harvested at 0, 20,60 and $90 \mathrm{~min}$, serially diluted to $10^{-4}$ in sterilized deionized water and spread on YPD plates. Plates were incubated at $30^{\circ} \mathrm{C}$ for $48 \mathrm{~h}$ and the colonies were counted. Viability was calculated as percentage of colony-forming units (CFU) at each time point in relation to the beginning of the experiment $(0 \mathrm{~min})$.

As a statistically significant decrease in cells growth rate was observed at 90 min for black BSG extracts, another assay was carried out under similar conditions. Cells were prepared in the same way as for viability measurement, except that they were suspended in phosphate buffered saline (PBS; $137 \mathrm{mM} \mathrm{NaCl}, 2.7 \mathrm{mM} \mathrm{KCl}$, $4.3 \mathrm{mM} \mathrm{Na}_{2} \mathrm{HPO}_{4}, 1.47 \mathrm{mM} \mathrm{KH}_{2} \mathrm{PO}_{4}, \mathrm{pH} 7.4$ ), instead of YPD medium. In PBS, cells are not able to grow and a lower value of viability may be related to a cytotoxic effect. Survival rates were calculated as percentage of CFU, assuming $100 \%$ survival for cells of the suspension before any treatment.

\subsection{Analysis of DNA Damage by the Yeast Comet Assay}

DNA damage was assessed by a recently developed yeast comet assay (Azevedo et al., 2011). Briefly, cell walls were digested with $2 \mathrm{mg} / \mathrm{mL}$ zymolyase $\left(20,000 \mathrm{U} / \mathrm{g}\right.$; ImmunO $\left.{ }^{\mathrm{TM}}-20 \mathrm{~T}\right)$, incubated at $30^{\circ} \mathrm{C}$ for $20 \mathrm{~min}$ and collected by centrifugation at $5000 \mathrm{rpm}, 4^{\circ} \mathrm{C}$ for $2 \mathrm{~min}$. Spheroplasts were then suspended in $1 \mathrm{~mL} \mathrm{~S}$ buffer $(1 \mathrm{M}$ sorbitol, $25 \mathrm{mM} \mathrm{KH}_{2} \mathrm{PO}_{4}, \mathrm{pH} \mathrm{6.5)} \mathrm{and} 80 \mu \mathrm{L}$ of this suspension were distributed by microtubes and collected by centrifugation at $5000 \mathrm{rpm}, 4{ }^{\circ} \mathrm{C}$ for $2 \mathrm{~min}$. Each pellet was suspended in $\mathrm{BSG}$ extracts diluted in water and exposed to the oxidant solution $\left(10 \mathrm{mM} \mathrm{H}_{2} \mathrm{O}_{2}\right)$ for $20 \mathrm{~min}$ at $4{ }^{\circ} \mathrm{C}$. Treated spheroplasts were collected from suspension by centrifugation at $5000 \mathrm{rpm}, 4{ }^{\circ} \mathrm{C}$ for $2 \mathrm{~min}$ and then embedded in $1.5 \%$ (w/v in $\mathrm{S}$ buffer) low melting agarose (LMA) at $35{ }^{\circ} \mathrm{C}$ and distributed by glass slides (slide coated with a water solution of $0.5 \% \mathrm{w} / \mathrm{v}$ normal-melting agarose), covered with a coverslip and placed on ice to solidify. Following exposure of the cells to the $\mathrm{H}_{2} \mathrm{O}_{2}$ treatment, the slides were incubated in the lysing buffer $(30 \mathrm{mM} \mathrm{NaOH}, 1 \mathrm{M} \mathrm{NaCl}, 0.05 \% \mathrm{w} / \mathrm{v}$ laurylsarcosine, $50 \mathrm{mM}$ EDTA, $10 \mathrm{mM}$ Tris-HCl, $\mathrm{pH}$ 10) for $20 \mathrm{~min}$ in order to lyse spheroplasts. Samples were incubated in electrophoresis buffer $(30 \mathrm{mM} \mathrm{NaOH}, 10 \mathrm{mM}$ EDTA, $10 \mathrm{mM}$ Tris-HCl, $\mathrm{pH} \mathrm{10})$ for $20 \mathrm{~min}$ and then submitted to electrophoresis in the same buffer for $10 \mathrm{~min}$ at $0.7 \mathrm{~V} / \mathrm{cm}$. After electrophoresis, the slides were incubated in neutralization buffer $(10 \mathrm{mM}$ Tris- $\mathrm{HCl}, \mathrm{pH} 7.4)$ for $10 \mathrm{~min}$, followed by consecutive $10 \mathrm{~min}$ incubations in $76 \%$ and $96 \%(\mathrm{v} / \mathrm{v})$ ethanol. The slides were then dried at room temperature and were visualized immediately or stored at $4{ }^{\circ} \mathrm{C}$ until observation. For visualization in a fluorescence microscope (Leica Microsystems DM fluorescence), the slides were stained with GelRed $(10 \mu \mathrm{g} / \mathrm{mL}$; Biotium) and representative images were acquired at magnification of $400 \times$ in order to obtain at least 20 random comets per sample that were analyzed with the CometScore version 1.5 software for the tail length (expressed in $\mu \mathrm{m}$ ). Error bars represent variability between the mean of at least three different slides obtained from biologically independent experiments.

\subsection{Flow Cytometry Analysis}

Cells were prepared as described for cell viability measurements, except that they were diluted to a density of 1.0 $\times 10^{6}$ cells $/ \mathrm{mL}$ and suspended in PBS $\left(137 \mathrm{mM} \mathrm{NaCl}, 2.7 \mathrm{mM} \mathrm{KCl}, 4.3 \mathrm{mM} \mathrm{Na}_{2} \mathrm{HPO}_{4}, 1.47 \mathrm{mM} \mathrm{KH}_{2} \mathrm{PO}_{4}, \mathrm{pH}\right.$ 7.4), instead of YPD medium. Five hundred microlitres of untreated cells were removed for autofluorescence measurement. Dichlorofluorescein diacetate $\left(\mathrm{H}_{2} \mathrm{DCFDA}\right.$; Sigma-Aldrich) $(50 \mu \mathrm{M}$ final concentration) was added as a fluorochrome to the reminder of the cells and cell suspension was further incubated at $30{ }^{\circ} \mathrm{C}, 200 \mathrm{rpm}$ for 1 $\mathrm{h}$ in the dark, washed twice with the same volume of PBS and distributed in aliquots for the different assay conditions. Cells were treated with diluted BSG extracts, $5 \mathrm{mM} \mathrm{H}_{2} \mathrm{O}_{2}$, or both and incubated at $30^{\circ} \mathrm{C}, 200 \mathrm{rpm}$ for $20 \mathrm{~min}$. Twenty thousand cells of each sample were analyzed by flow cytometry in an Epics XLTM cytometer (Beckman Coulter) equipped with a $15 \mathrm{~mW}$ argon-ion laser emitting at $488 \mathrm{~nm}$. Green fluorescence was collected through a $488 \mathrm{~nm}$ blocking filter, a $550 \mathrm{~nm}$ long-pass dichroic and a $225 \mathrm{~nm}$ bandpass filter. Data were analyzed and histograms were made with the Flowing software version 2.5.0.

\subsection{Statistical Analysis}

All results are the mean and standard deviation (SD) values of at least three independent experiments. Differences in means were detected using one-way ANOVA and Tukey's test. The software employed for statistical analysis was Graphpad Prism, version 5 for Windows. Asterisks indicate differences considered statistically significant: * indicates $p<0.05, * *$ indicates $p<0.01$, and $* * *$ indicates $p<0.001$, when compared to the respective control. 


\section{Results}

\subsection{Viability Assays}

To investigate a possible toxicity of BSG extracts, the growth rate of yeast cultures was assessed in the presence of 2-fold diluted pilsen and black BSG extracts during 90 min (Figure 1). As can be observed in Figure 1, cells without any treatment (control) or incubated with BSG extracts displayed an increase in CFU's during the 90 min incubation. After 60 min incubation, a slight decrease in viability was observed in yeast cells treated with black BSG extracts comparing to control, which becomes statistically significant $(p<0.05)$ after 90 min incubation.

To evaluate whether the effect of black BSG extract on yeast viability was by inhibition of proliferation or by induction of loss of viability, yeast cells were then incubated with black BSG extracts in PBS buffer instead of YPD. The comparison of cell viability in control with cells treated with black BSG extract showed not statistically significant differences ( $p>0.05$, data not shown). Therefore, the reduction in viability registered in yeast cells incubated with black BSG (Figure 1) could be explained by an adaptation of yeast cells to the new growth conditions. So, $20 \mathrm{~min}$ of incubation time was chosen for the following assay, since $S$. cerevisiae viability is not affected by the BSG extracts.

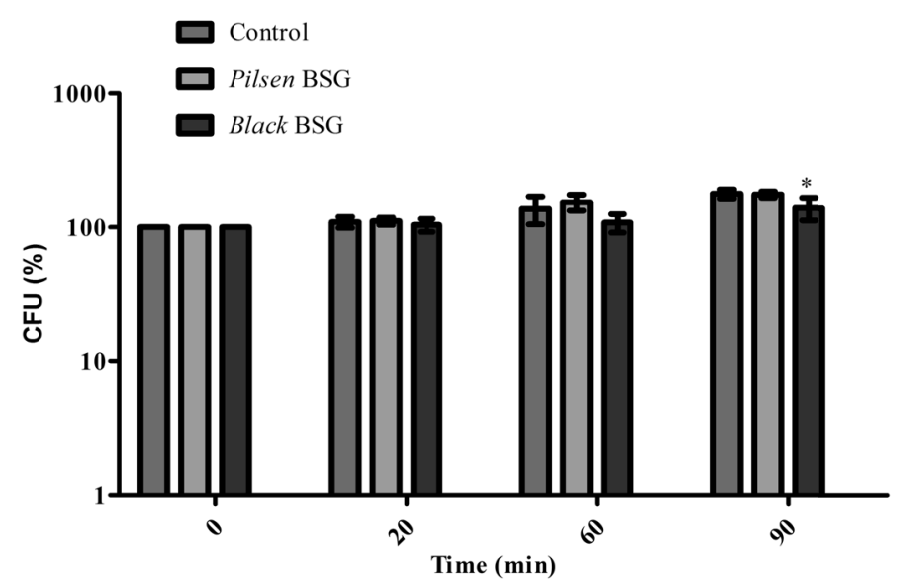

Figure 1. Viability of yeast cells when incubated with water (control) or 2-fold diluted BSG extracts in YPD medium. Mean \pm SD values are from three independent experiments $(*$ represents $p<0.05$ )

\subsection{Analysis of DNA Damage by the Yeast Comet Assay}

As can be seen in Figure 2, treatment of yeast cells with $10 \mathrm{mM} \mathrm{H}_{2} \mathrm{O}_{2}$ dramatically increased $(p<0.001)$ comet tail length comparing to cells in the presence of deionized water. When yeast spheroplasts were incubated with pilsen $\mathrm{BSG}$ extracts and exposed to $\mathrm{H}_{2} \mathrm{O}_{2}$ (Figure 2A, BSG/10 - 200 $+\mathrm{H}_{2} \mathrm{O}_{2}$ ), a dose dependent decrease in comet tail length was observed, when compared to the positive control (Figure $2 \mathrm{~A}, \mathrm{H}_{2} \mathrm{O}_{2}$ ). Results showed that 10 and 20 -fold diluted pilsen BSG extracts significantly $(p<0.05)$ reduced DNA oxidative damage induced by $\mathrm{H}_{2} \mathrm{O}_{2}$, when compared to yeast cells incubated in the presence of $\mathrm{H}_{2} \mathrm{O}_{2}$. In fact, nearly a 1.5 -fold decrease in comet tail was observed in cells treated with a 10-fold diluted extract (Figure 2A, BSG/10 $+\mathrm{H}_{2} \mathrm{O}_{2}$ ). The oxidative DNA damage was significantly $(p<0.001)$ reduced in the presence of black BSG extract leading to a 5-fold decrease in comet tail length in a 10-fold dilution (Figure 2B, BSG/10 $+\mathrm{H}_{2} \mathrm{O}_{2}$ ). No protective effect of black BSG extract was observed at 200-fold dilution comparing to control. 

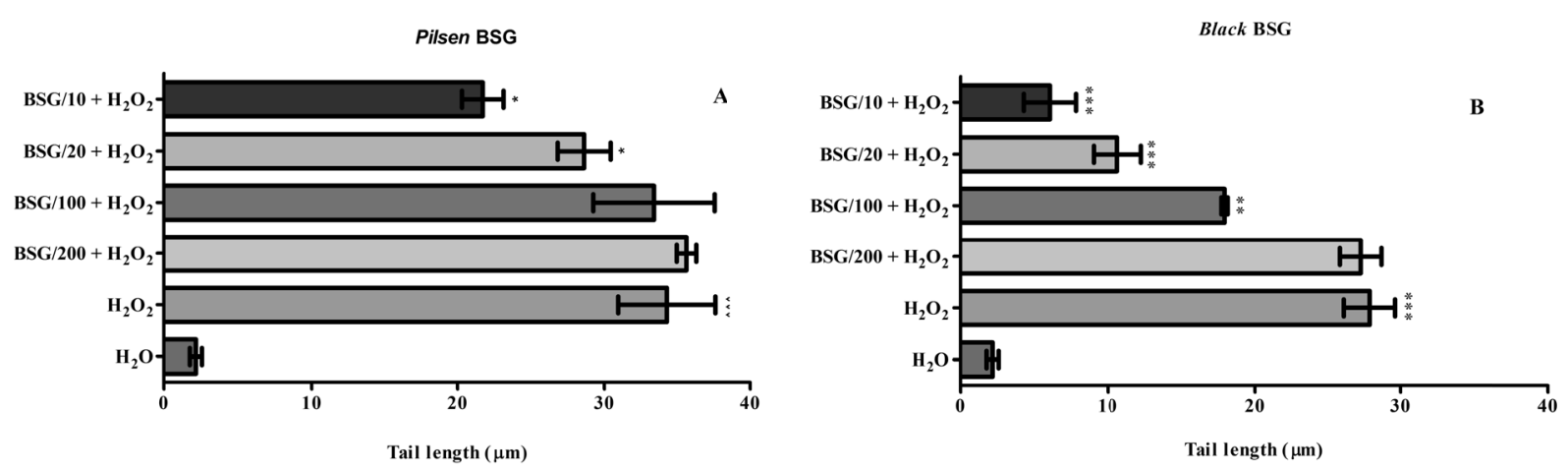

Figure 2. Pilsen (A) and black (B) BSG extracts protect DNA of S. cerevisiae cells from oxidative damage by $\mathrm{H}_{2} \mathrm{O}_{2}$. Yeast spheroplasts were incubated with BSG $(10,20,100$ or 200 -fold diluted in water, respectively, BSG/10 $+\mathrm{H}_{2} \mathrm{O}_{2}, \mathrm{BSG} / 20+\mathrm{H}_{2} \mathrm{O}_{2}, \mathrm{BSG} / 100+\mathrm{H}_{2} \mathrm{O}_{2}$ and BSG/200 $+\mathrm{H}_{2} \mathrm{O}_{2}$ ) simultaneously with $10 \mathrm{mM} \mathrm{H}_{2} \mathrm{O}_{2}$ for 20 min. Positive control $\left(\mathrm{H}_{2} \mathrm{O}_{2}\right)$ represents treatment exclusively with $10 \mathrm{mM} \mathrm{H}_{2} \mathrm{O}_{2}$; and negative control $\left(\mathrm{H}_{2} \mathrm{O}\right)$ represents treatment exclusively with $\mathrm{H}_{2} \mathrm{O}$. DNA damage was analyzed by the comet assay method. Mean $\pm \mathrm{SD}$ values are from three independent experiments. (*** represents $p<0.001,{ }^{* *}$ represents $p<0.01$ and * represents $p<0.05$ )

\subsection{Flow Cytometry Analysis}

The antioxidant activity of pilsen and black BSG extracts has been further investigated by flow cytometry using the fluorochrome $\mathrm{H}_{2}$ DCFDA as a marker of intracellular oxidation (Bartosz, 2006). The diacetate form of dichlorofluorescein diffuses freely into cells through the plasma membrane. Inside cells, $\mathrm{H}_{2}$ DCFDA is deacetylated by intracellular esterases to dichlorofluorescein $\left(\mathrm{H}_{2} \mathrm{DCF}\right) . \mathrm{H}_{2} \mathrm{DCF}$ is hydrophilic and accumulates inside cells due to impermeability of membrane. Oxidation increases fluorescence of $\mathrm{H}_{2} \mathrm{DCF}$ so it can be used as a marker for intracellular oxidation.

To investigate whether BSG extracts protect cells from oxidative stress, mid-log growth phase cells were incubated with $\mathrm{H}_{2}$ DCFDA before treatment with BSG extracts diluted in PBS or $5 \mathrm{mM} \mathrm{H}_{2} \mathrm{O}_{2}$ for $20 \mathrm{~min}$. The intracellular fluorescence was then measured by flow cytometry. The histograms were obtained by sorting yeast cells according to their size and roughness (Figure3A). The $\mathrm{x}$-axis corresponds to the fluorescence intensity and $\mathrm{y}$-axis is the number of cells. In circumstances of oxidative DNA damage, higher fluorescence values are expected with the consequent shift of the peaks to the right. As can be seen, oxidative shock by $\mathrm{H}_{2} \mathrm{O}_{2}$ (Figure 3A-2) induces an increase of intracellular oxidation and, hence, fluorescence of the population of cells shifted right compared to non-treated cells (Figure 3A-1). However, fluorescence significantly decreased in cells simultaneously treated with 20-fold diluted BSG extracts and $5 \mathrm{mM} \mathrm{H}_{2} \mathrm{O}_{2}$, (Figure 3A-3 and A-4). These results suggest that pilsen and black BSG extracts protect yeast cells against oxidative shock. Antioxidant activity was also observed when BSG extracts were diluted in PBS: 50, 75 and 100-fold. 


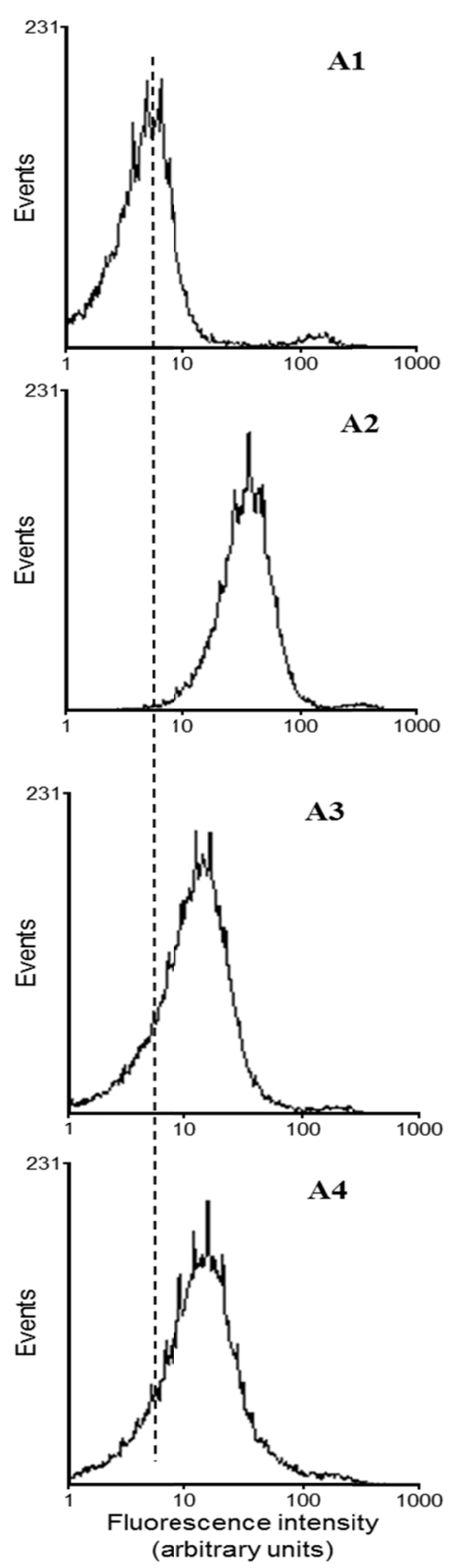

Figure 3. BSG extracts decrease intracellular oxidation by $\mathrm{H}_{2} \mathrm{O}_{2}$ in S. cerevisiae cells. (A) - Representation of the obtained histogram for fluorescence of the oxidized form of $\mathrm{H}_{2} \mathrm{DCF}$ (A-1); or after incubation with $5 \mathrm{mM} \mathrm{H}_{2} \mathrm{O}_{2}$ for $20 \mathrm{~min}$, washed with PBS and analyzed by flow cytometry (A-2); or incubation with pilsen or black BSG extract diluted 20 -fold and $5 \mathrm{mM} \mathrm{H}_{2} \mathrm{O}_{2}$ for 20 min, washed with PBS and analyzed by flow cytometry (A-3 and A-4, respectively). Data are from one representative experiment from at least three independent experiments

The antioxidant effect was also quantified by determining the fluorescence average in each experimental situation (Table 1). Results also evidence a dose dependent effect of BSG extracts. An approximate 2-fold increase in fluorescence intensity was observed in yeast cells treated with $5 \mathrm{mM} \mathrm{H}_{2} \mathrm{O}_{2}$ for 20 min comparing to untreated control cells $\left(\mathrm{H}_{2} \mathrm{O}\right)$. Under the same experimental conditions, intracellular oxidation of cells induced by $\mathrm{H}_{2} \mathrm{O}_{2}$ was reduced to $52 \%$ and $58 \%$ following the treatment with 20 -fold dilution pilsen and black BSG extracts, respectively. However, no significant $(p>0.05)$ protective effect was observed for a 100 -fold dilution. 
Table 1. Treatment of S.cerevisiae cells with BSG extracts decreased the intracellular oxidative damage by $\mathrm{H}_{2} \mathrm{O}_{2}$. Yeast spheroplasts were simultaneously treated with 20-, 50-, 75- and 100-fold diluted BSG extracts in PBS and $5 \mathrm{mM} \mathrm{H}_{2} \mathrm{O}_{2}$. The negative control $\left(\mathrm{H}_{2} \mathrm{O}\right)$ reflects the amount of DNA damage in cells without exposure to BSG extracts and $\mathrm{H}_{2} \mathrm{O}_{2}$. The 20-fold diluted BSG extract reflects the amount of DNA damage in cell only treated with BSG extracts. Oxidative damage was analyzed by flow cytometry (see Materials and Methods). Fluorescence average $\pm \mathrm{SD}$ are from three independent experiments $(* * *$ represents $p<0.001)$

\begin{tabular}{lll}
\hline \multirow{2}{*}{ Experimental condition } & \multicolumn{2}{c}{ Fluorescence average \pm SD } \\
\cline { 2 - 3 } & Pilsen BSG extract & Black BSG extract \\
\hline $\mathrm{H}_{2} \mathrm{O}$ & $1294 \pm 65^{* * *}$ & \\
$\mathrm{H}_{2} \mathrm{O}_{2}$ & $3019 \pm 151$ & $1311 \pm 66^{* * *}$ \\
$\mathrm{BSG} / 20$ & $1271 \pm 64^{* * *}$ & $1743 \pm 87^{* * *}$ \\
$\mathrm{BSG} / 20+\mathrm{H}_{2} \mathrm{O}_{2}$ & $1569 \pm 78^{* * *}$ & $2108 \pm 105^{* * *}$ \\
$\mathrm{BSG} / 50+\mathrm{H}_{2} \mathrm{O}_{2}$ & $2012 \pm 101^{* * *}$ & $2310 \pm 116^{* * *}$ \\
$\mathrm{BSG} / 75+\mathrm{H}_{2} \mathrm{O}_{2}$ & $2294 \pm 115^{* * *}$ & $3016 \pm 151$ \\
$\mathrm{BSG} / 100+\mathrm{H}_{2} \mathrm{O}_{2}$ & $2971 \pm 149$ & \\
\hline
\end{tabular}

\section{Discussion}

This work clearly demonstrates that BSG extracts obtained from pilsen and black malt types exert dose-dependent protective effects against the genotoxic effects induced by $\mathrm{H}_{2} \mathrm{O}_{2}$ in yeast cells. However, oxidative protective activity of pilsen BSG extract was less effective comparing to black BSG extract (Figure 2), suggesting a less antigenotoxic activity. Beneficial properties of BSG extracts may be related to bioactive compounds with antioxidant activity, which prevent DNA oxidative damage induced by strong reactive ROS (Bellion et al., 2010). Therefore, the differences observed for pilsen and black BSG extracts can be ascribed to the different composition of the extracts. Ferulic and $p$-coumaric acids are well known phenolic compounds present in high concentrations in BSG (Moreira et al., 2013). Moreover, previous studies have demonstrated that ferulic acid (FA) protects DNA against oxidative damage caused by $\mathrm{H}_{2} \mathrm{O}_{2}$, as measured by the comet assay (Wang, Sun, Cao, Song, \& Tian, 2008). Recently, McCarthy et al. (2012) also demonstrated that FA at $1 \mu \mathrm{g} / \mathrm{mL}$ leads to a $50 \%$ reduction of DNA oxidative damage in $\mathrm{U} 937$ cells treated with $\mathrm{H}_{2} \mathrm{O}_{2}$ using the comet assay. In a study conducted by Wang et al. (2008) and also applying the comet assay, the FA ester of oligosaccharides present in wheat bran were able to protect against $\mathrm{H}_{2} \mathrm{O}_{2}$ induced DNA damage in normal human peripheral blood lymphocytes. In all these works the observed effects were mainly attributed to the antioxidant capacity of the FA moiety.

The results reported herein for yeast comet assay did not directly correlate with previously reported data (Moreira et al., 2013), which demonstrated that pilsen BSG extract exhibited the highest antioxidant activity and higher phenolic content. This difference can be partially be explained by the oxidative mechanism and radical system involved in antioxidant evaluation, which was shown to interfere in the evaluation of the antioxidant activity of a selected sample (Shahidi \& Chandrasekara, 2010). The radical systems used in the experiments carried out in our previous work (Moreira et al., 2013) were based on in vitro assays, while the comet assay is developed in yeast cells involving a high complex chemical environment. Additionally, the observed differences pilsen and black BSG extracts regarding preventive DNA oxidative damage may be attributed to melanoidins compounds. Melanoidins are generated during malt kilning through the Maillard reaction and are, therefore, mainly present in black malts. Melanoidins can be defined as brown high molecular weight compounds formed in the last stages of the Maillard reaction of thermally treated foods. Several studies reported that these high molecular weight compounds may chelate iron and potentially inhibit the metal-dependent processes leading to DNA damage (Coghe, Gheeraert, Michiels, \& Delvaux, 2006; Inns, Buggey, Booer, Nursten, \& Ames, 2007). In agreement, the antioxidant properties of BSG extracts can be attributed to chemical components, which may have a scavenging effect on $\mathrm{H}_{2} \mathrm{O}_{2}$ and/or an induction of oxidative stress response and/or induction of DNA damage repair. The mechanism of the protective action of the bioactive compounds is not clearly understood. The commonly accepted mechanism is the scavenging of ROS by polyphenols since they are well-known due to their strong antioxidant activity. However, mechanisms involving metal binding have also been proposed (Lopes, Schulman, \& Hermes-Lima, 1999; Perron, García, Pinzón, Chaur, \& Brumaghim, 2011; Perron, Hodges, Jenkins, \& Brumaghim, 2008). Perron et al. (2008) have confirmed that polyphenol compounds, such as catechin, quercetin, gallic, protocatechuic and vanillic acids inhibit DNA damage by a mechanism involving iron binding. They reported that the iron oxidation observed upon binding to polyphenol compounds may result in an iron (III) 
complex that cannot be reduced by cellular reductants to catalytically generate a hydroxyl radical. Therefore, the determination how iron coordination controls the antioxidant activity of these extracts is important to better understanding their biological activity.

Antioxidant activity assessed by flow cytometry assays demonstrated that oxidative damage in yeast cells can be reduced to approximately $50 \%$ in the presence of 20 -fold diluted BSG extracts. These results strongly suggest that BSG extracts reduce intracellular ROS in yeast cells, supporting the hypothesis the same extracts possess ROS scavenging properties and/or efficiently recycle endogenous scavenger cellular proteins such as glutathione, thioredoxin, superoxide dismutase, catalase, and/or induce the pentose phosphate pathway activity in regenerating NADPH (Azevedo et al., 2011).

\section{Conclusions}

The results from the current study revealed that BSG extracts from pilsen and black malts may have strong in vivo antioxidant activity protecting Saccharomyces cerevisiae cells against oxidative DNA damage. Black BSG extracts exhibited a 5-fold reduction in the genotoxic effects of $\mathrm{H}_{2} \mathrm{O}_{2}$, while pilsen BSG extracts exhibited a 2-fold reduction. Antioxidant activity assessed by flow cytometry assays demonstrated that the $\mathrm{H}_{2} \mathrm{O}_{2}$ oxidant activity can be reduced to approximately $50 \%$ in yeast cells in the presence of 20 -fold diluted BSG extracts.

\section{Acknowledgements}

This work received financial support from the European Union (FEDER Funds through COMPETE) and National Funds (FCT, Fundação para a Ciência e a Tecnologia) through project Pest-C/EQB/LA0006/2013 and PEst-C/BIA/UI4050/2011. The work also received financial support from the European Union (FEDER funds) under the framework of QREN through Project NORTE-07-0124-FEDER-000069. DOC receives a postdoc grant through the project Operação Norte-01-0145-FEDER-000011. MMM wishes to acknowledge to FCT for her postdoctoral grant (SFRH/BPD/97049/2013). The authors also thank Unicer-Bebidas de Portugal, S. A. for the supply of BSG samples.

\section{References}

Azevedo, F., Marques, F., Fokt, H., Oliveira, R., \& Johansson, B. (2011). Measuring oxidative DNA damage and DNA repair using the yeast comet assay. Yeast, 28(1), 55-61. https://doi.org/10.1002/yea.1820

Bartolomé, B., Santos, M., Jiménez, J. J., del Nozal, M. J., \& Gómez-Cordovés, C. (2002). Pentoses and hydroxycinnamic acids in brewer's spent grain. Journal of Cereal Science, 36(1), 51-58. https://doi.org/10.1006/jcrs.2002.0442

Bartosz, G. (2006). Use of spectroscopic probes for detection of reactive oxygen species. Clinica Chimica Acta, 368(1-2), 53-76. https://doi.org/10.1016/j.cca.2005.12.039

Bellion, P., Digles, J., Will, F., Dietrich, H., Baum, M., Eisenbrand, G., \& Janzowski, C. (2010). Polyphenolic apple extracts: Effects of raw material and production method on antioxidant effectiveness and reduction of DNA damage in caco-2 cells. Journal of Agricultural and Food Chemistry, 58(11), 6636-6642. https://doi.org/10.1021/jf904150x

Coghe, S., Gheeraert, B., Michiels, A., \& Delvaux, F. R. (2006). Development of Maillard Reaction Related Characteristics During Malt Roasting. Journal of the Institute of Brewing, 112(2), 148-156. https://doi.org/10.1002/j.2050-0416.2006.tb00244.x

Gomes, C. A., Girão da Cruz, T., Andrade, J. L., Milhazes, N., Borges, F., \& Marques, M. P. M. (2003). Anticancer activity of phenolic acids of natural or synthetic origin: A structure-activity study. Journal of Medicinal Chemistry, 46(25), 5395-5401. https://doi.org/10.1021/jm030956v

Henle, E. S., Luo, Y., Gassmann, W., \& Linn, S. (1996). Oxidative damage to DNA constituents by iron-mediated Fenton Reactions: The deoxyguanosine family. Journal of Biological Chemistry, 271(35), 21177-21186. https://doi.org/10.1074/jbc.271.35.21177

Inns, E. L., Buggey, L. A., Booer, C., Nursten, H. E., \& Ames, J. M. (2007). Effect of heat treatment on the antioxidant activity, color, and free phenolic acid profile of malt. Journal of Agricultural and Food Chemistry, 55(16), 6539-6546. https://doi.org/10.1021/jf0710231

Kim, E. O., Min, K. J., Kwon, T. K., Um, B. H., Moreau, R. A., \& Choi, S. W. (2012). Anti-inflammatory activity of hydroxycinnamic acid derivatives isolated from corn bran in lipopolysaccharide-stimulated Raw 264.7 macrophages. Food and Chemical Toxicology, 50(5), 1309-1316. https://doi.org/10.1016/j.fct.2012. 02.011 
Lopes, G. K. B., Schulman, H. M., \& Hermes-Lima, M. (1999). Polyphenol tannic acid inhibits hydroxyl radical formation from Fenton reaction by complexing ferrous ions. Biochimica et Biophysica Acta (BBA) General Subjects, 1472(1-2), 142-152. https://doi.org/10.1016/S0304-4165(99)00117-8

Mager, W. H., \& Winderickx, J. (2005). Yeast as a model for medical and medicinal research. Trends in Pharmacological Sciences, 26(5), 265-273. https://doi.org/10.1016/j.tips.2005.03.004

Marques, F., Azevedo, F., Johansson, B., \& Oliveira, R. (2011). Stimulation of DNA repair in Saccharomyces cerevisiae by Ginkgo biloba leaf extract. Food and Chemical Toxicology, 49(6), 1361-1366. https://doi.org/10.1016/j.fct.2011.03.020

McCarthy, A. L., O’Callaghan, Y. C., Connolly, A., Piggott, C. O., FitzGerald, R. J., \& O’Brien, N. M. (2012). Phenolic extracts of brewers' spent grain (BSG) as functional ingredients - Assessment of their DNA protective effect against oxidant-induced DNA single strand breaks in U937 cells. Food Chemistry, 134(2), 641-646. https://doi.org/10.1016/j.foodchem.2012.02.133

Meneses, N. G. T., Martins, S., Teixeira, J. A., \& Mussatto, S. I. (2013). Influence of extraction solvents on the recovery of antioxidant phenolic compounds from brewer's spent grains. Separation and Purification Technology, 108, 152-158. https://doi.org/10.1016/j.seppur.2013.02.015

Moreira, M. M., Morais, S., Barros, A. A., Delerue-Matos, C., \& Guido, L. F. (2012). A novel application of microwave-assisted extraction of polyphenols from brewer's spent grain with HPLC-DAD-MS analysis. Analytical and Bioanalytical Chemistry, 403(4), 1019-1029. https://doi.org/10.1007/s00216-011-5703-y

Moreira, M. M., Morais, S., Carvalho, D. O., Barros, A. A., Delerue-Matos, C., \& Guido, L. F. (2013). Brewer's spent grain from different types of malt: Evaluation of the antioxidant activity and identification of the major phenolic compounds. Food Research International, 54(1), 382-388. https://doi.org/10.1016/ j.foodres.2013.07.023

Mussatto, S. I., Dragone, G., \& Roberto, I. C. (2006). Brewers' spent grain: Generation, characteristics and potential applications. Journal of Cereal Science, 43(1), 1-14. https://doi.org/10.1016/j.jcs.2005.06.001

Mussatto, S. I., Dragone, G., \& Roberto, I. C. (2007). Ferulic and p-coumaric acids extraction by alkaline hydrolysis of brewer's spent grain. Industrial Crops and Products, 25(2), 231-237. https://doi.org/ 10.1016/j.indcrop.2006.11.001

Perron, N. R., García, C. R., Pinzón, J. R., Chaur, M. N., \& Brumaghim, J. L. (2011). Antioxidant and prooxidant effects of polyphenol compounds on copper-mediated DNA damage. Journal of Inorganic Biochemistry, 105(5), 745-753. https://doi.org/10.1016/j.jinorgbio.2011.02.009

Perron, N. R., Hodges, J. N., Jenkins, M., \& Brumaghim, J. L. (2008). Predicting How Polyphenol Antioxidants Prevent DNA Damage by Binding to Iron. Inorganic Chemistry, 47(14), 6153-6161. https://doi.org/ 10.1021/ic7022727

Rank, J., Syberg, K., \& Jensen, K. (2009). Comet assay on tetraploid yeast cells. Mutation Research/Genetic Toxicology and Environmental Mutagenesis, 673(1), 53-58. https://doi.org/10.1016/j.mrgentox.2008.11.014

Shahidi, F., \& Chandrasekara, A. (2010). Hydroxycinnamates and their in vitro and in vivo antioxidant activities. Phytochemistry Reviews, 9(1), 147-170. https://doi.org/10.1007/s11101-009-9142-8

Vieira, E., Rocha, M. A. M., Coelho, E., Pinho, O., Saraiva, J. A., Ferreira, I. M. P. L. V. O., \& Coimbra, M. A. (2014). Valuation of brewer's spent grain using a fully recyclable integrated process for extraction of proteins and arabinoxylans. Industrial Crops and Products, 52(0), 136-143. https://doi.org/10.1016/ j.indcrop.2013.10.012

Wang, J., Sun, B., Cao, Y., Song, H., \& Tian, Y. (2008). Inhibitory effect of wheat bran feruloyl oligosaccharides on oxidative DNA damage in human lymphocytes. Food Chemistry, 109(1), 129-136. https://doi.org/10.1016/j.foodchem.2007.12.031 


\section{Abbreviations}

BER, Base excision repair;

BSG, Brewer's spent grain;

CFU, Colony forming units;

EBC, European Brewery Convention;

FA, Ferulic acid;

$\mathrm{H}_{2}$ DCFDA, Dichlorofluorescein diacetate;

$\mathrm{H}_{2}$ DCF, Dichlorofluorescein;

MAE, Microwave-assisted extraction;

NER, Nucleotide excision repair;

OD, Optical density;

ROS, Reactive oxygen species;

$\mathrm{SD}$, Standard deviation.

\section{Copyrights}

Copyright for this article is retained by the author(s), with first publication rights granted to the journal.

This is an open-access article distributed under the terms and conditions of the Creative Commons Attribution license (http://creativecommons.org/licenses/by/4.0/). 